\title{
Isolation and characterization of streptococcus bovis from rumencontent of awassi sheep in iraq
}

\author{
A. J. A. Al emery \\ Coll. of Vet.Med./ Unive. \\ of Al-Qadisiya
}

\author{
A. A. Yousif \\ Coll. of Vet.Med./ Unive. \\ of Baghdad
}

\author{
H. A. Al-Hilaly \\ Coll. of Med./Unive.of \\ Al-Qadisiya
}

\begin{abstract}
This is the first study in Iraq aimed to isolate and characterize Streptococcus bovis from rumen of Awassi sheep. Ten sheep with different ages fed on grain base diet for three days were used to collect 20 ruminal fluid samples twice at fourth and fifth days by rumenocentesis method, samples cultured on selective media (Modified membrane-bovis agar(M-BA), broth of basal medium and modified blood brain heart infusion), the isolates were identified according to their morphological, physiological ,biochemical tests and serological by Lancefield group.Cultural characteristic on the selective medium M-BA showed two types of streptococci :first type (23) comprised the majority of isolates ,this type characterized by high acid producing streptococci formed mucoid ,creamy ,orange -centered colonies and second type (4) characterize by low acid producing formed small white colonies .Morphologically the isolates were identified as gram positive, the cells were oval or spherical, singles, pairs \& short chains of 4 to 8 cells. The organisms were found to full under the Lancefield group D.All isolated bacteria grew on broth of basal medium post incubation at $45 \mathrm{C}^{\circ}$, but not grew at $10 \mathrm{C}^{\circ}$ and $50 \mathrm{C}^{\circ}$. Adding of $2 \% \mathrm{NaCl}$ permit the growth, while in $6.5 \% \mathrm{NaCl}$ didn't grow. And did not grew on adding $0.04 \%$ Potassium tellurite .All isolates produced lactic acid but ammonia production from arginine was negative, no hemolysis on blood agar. All isolates ferment starch, lactose, fructose, glucose, raffinose and cellobiose.The results of culturing and Physiological and biochemical tests showed that 27 isolates has the characterictices of Streptococcus bovis in 3 types $\left(\mathrm{S}_{1}, \mathrm{~S}_{2} \& \mathrm{~S}_{3}\right)$ ,first type of colony divided into two strain $\left(S_{1} 15\right)\left(S_{2} 8\right)$ according to difference In arabinose. And $\left(\mathrm{S}_{3}\right)$ called on the second type white pigmented isolates which did not ferment inulin
\end{abstract}

\section{Introduction}

Streptococcus bovis was recognized as an important ruminal bacterium in terms of carbohydrate fermentation in early 1950s (1) but was not classified as an active proteolytic bacterium until 30 years later. In different animals the population of this bacterium remains lower under normal feeding ( forage diet ), but its numbers can increases significantly following dietary change when large of starch or sugars were added to the diet (2,3,4). Streptococcus bovis is a gram-positive bacteria, it was a ruminal bacterium that can produce large amounts of lactate and its involved in the onset of ruminal acidosis ( 1,5 ) .During period of rapid growth, lactic acid production by S.bovis can cause decline in rumen $\mathrm{pH}$ to the point where growth rates of other rumen bacteria are inhibited (6,7,8).Kamra ( 9) showed that the anaerobic conditions in the rumen are maintained by gases generated during fermentation e.g. Carbone dioxide , methane and traces hydrogen, and some of the oxygen with feed consumed by the animal is utilized by the facultative anaerobes present in the rumen and thus a perfect anaerobic condition is generated and maintained.Hungate (2) was developed technique "roll tube or hungate method"for cultivation of strict anaerobes in rumen, and this technique is very convenient for isolation of $S$. bovis. This study aimed to determine the presence of $S$. bovis in rumen of sheep fed with grain base diet and to characterize the isolates by different bacteriological, biochemical and serological methods. 


\section{Material and methods}

1- Animals:- Ten Awassi sheep in different ages were run as a single flock on alfa alfa and green berseem grass pasture sheep were housed indoors in individual pens and fed on high grain-based diet with access to fresh water at all times for three days were used for isolation of Streptococcus bovis at fourth (10 samples ) and fifth days (10 samples) from ruminal fluids of these animals.

\section{2- Local modified anaerobic apparatus}

A local anaerobic apparatus was designed by As'ad jassim and Afaf Abdulrahman similar to hungate apparatus(2) with some modification and used for purification of commercial carbon dioxide gas by passage on heated copper column to forming copper oxide (Picture No1).

The apparatus consist from:-

$1-\mathrm{CO}_{2}$ tube $5 \mathrm{Kg}$ (Aeroticiv ,Italy) $2-\mathrm{CO}_{2}$ regulator3-Rubber conduit hose4-the pyrex glass column consist of an a-inner glass (65 $x 1.5 \mathrm{~cm}$ ) inserted with heater are used to attach the electrical supply

b-outer glass $(75 \mathrm{x} 3 \mathrm{~cm})$ was provided by glass stopper was contain two opens for enter $\mathrm{CO}_{2}$ gas and electrical wire to apparatus.5-Copper wire 5 meter is wrapped around an inner glass6- Holder 7-filter 8electeric supply 9-Conduit hose was divived into two leads $(10,11)$ provided with needles gauge 20 at its end for flushing the flask and roll tubes at same time with $\mathrm{O}_{2}$ free $\mathrm{CO}_{2}$.

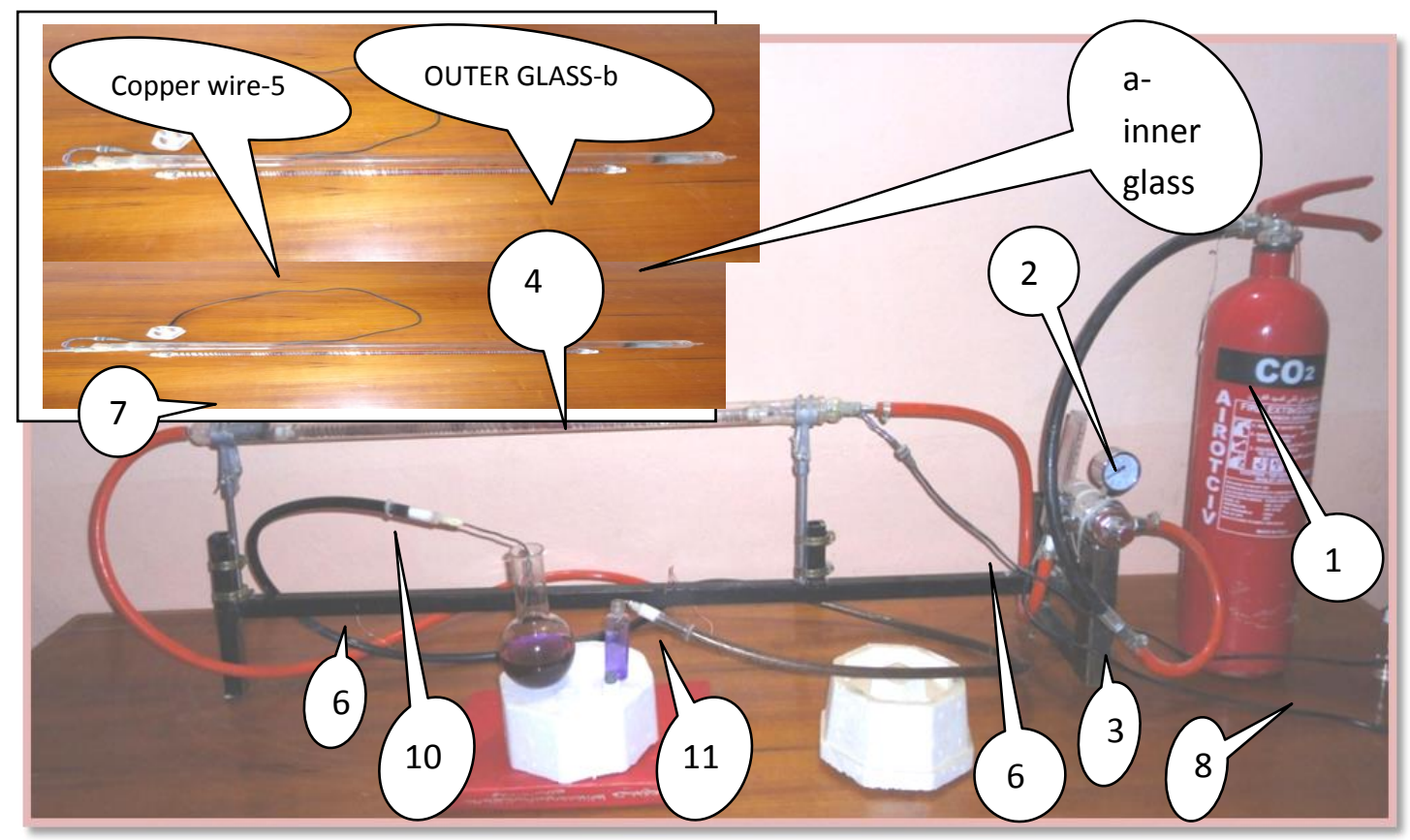

Picture No. (1) local anaerobe apparatus

\section{3-Solution and media:-}

a-Reducing solution prepared a freshly:each $1 \mathrm{ml}$ containing $0.026 \mathrm{~g}$ cysteine $-\mathrm{HCl}$ and $0.026 \mathrm{~g} \mathrm{Na}_{2} \mathrm{~S}_{9} 9 \mathrm{H}_{2} \mathrm{O}$ after boiling then pre -reduced by bubbling with $\mathrm{CO}_{2}$ gas on ice until cold . $t$ This solution was used for preparation of media

b-Carbonate solution: - $\quad\left(8 \% \mathrm{Na}_{2} \mathrm{CO}_{3}\right.$ solution), used for preparation of media .
c-Resazurin solution:-0.1g resazurin in 100 $\mathrm{ml}$ distilled water.

d- The anaerobic dilution solution(ADS) contained $7.5 \%$ mineral solution I $(0.6 \%$ $\left.\mathrm{K}_{2} \mathrm{HPO}_{4}\right)$ and $7.5 \%$ mineral solution II $\left[\begin{array}{lll}1.2 & \% & \mathrm{NaCl}\end{array}, 1.2 \%\left(\mathrm{NH}_{4}\right)_{2} \mathrm{SO}_{4}, 0.6 \%\right.$ $\mathrm{KH}_{2} \mathrm{PO}_{4} \quad, 0.12 \quad \% \quad \mathrm{CaCl} .2 \mathrm{H}_{2} \mathrm{O} \quad, 0.25 \%$ $\left.\mathrm{MgSo}_{4} .7 \mathrm{H}_{2} \mathrm{O}\right], 0.1 \%$ Resazurin solution. Make up to volume less $7 \%$ with distilled 
water, autoclave at $121 \mathrm{C}^{\circ}-15 \mathrm{Ib}$ pressure for 15 min. Gassing directly with $\mathrm{CO} 2$ then add $\begin{array}{lllll}2 \% & \text { cysteine solution and } 5 \% & \mathrm{Na}_{2} \mathrm{Co}_{3}\end{array}$ solution ,continue gassing until reduced and sealed

(10).

e- Modified membrane- bovis agar (MBA) medium was prepared according to (11) is highly selective medium for cultivate of $\mathrm{S}$. bovis , the medium contained ( $\mathrm{g} / 100 \mathrm{ml})$ :- $0.2\left(\mathrm{NH}_{4}\right)_{2} \mathrm{SO}_{4} ; 0.01$ yeast extract ;0.4 inulin ;0.3 raffinose hydrate ;0.1 sodium beta-glycerophosphate;0.005 sodium azide $; 0.01 \mathrm{NaCl} ; 0.005$ bromocresol purple ;0.02 $\mathrm{KCl} ; 0.02 \mathrm{MgSo}_{4} .7 \mathrm{H}_{2} \mathrm{O} ; 0.01 \mathrm{~K}_{2} \mathrm{HPO}_{4}$ and 1.2 agar . After dissolving the ingredients, 7 $\mathrm{ml}$ of $8 \% \mathrm{NaCO}_{3}$ and $1 \mathrm{ml}$ of reducing solution were added the solution was heated gently to dissolve all ingredients and the $\mathrm{pH}$ was adjusted to 6.8 . f- Basal medium broth was prepared refer to (12).

The broth prepared(Per liter)from:- 292 $\mathrm{mg} \mathrm{K} \mathrm{K}_{2} \mathrm{PO}_{4} ; 292 \mathrm{mg} \mathrm{KH} \mathrm{KO}_{44} ; 480 \mathrm{mg}$ $\left(\mathrm{NH}_{4}\right)_{2} \quad \mathrm{SO}_{4} \quad ; 480 \quad \mathrm{mg} \quad \mathrm{NaCl} \quad ; \quad 100$ mgMgSo $4.7 \mathrm{H}_{2} \mathrm{O} ; 64 \mathrm{mg} \mathrm{CaCl} .2 \mathrm{H}_{2} \mathrm{O} ; 4 \mathrm{~g} \mathrm{NaCo}$ ; 0.6 cysteine hydrochloride ,1 g trypticase ;0.5 yeast extract and $4 \mathrm{~g}$ glucose. The broth was adjusted to $\mathrm{pH} 6.7$ and the final $\mathrm{pH}$ was never less than 6.5 .

g- Modified blood brain heart infusion. was modified by adding reducing solution to brain heart infusion, after sterilization the tubes contained medium applied in water bath at $45 \mathrm{C}^{\circ}$,then $5 \%$ of sheep blood was added ( 13) the medium was prepared anerobically same as above media

i- Modified MRS-agar medium :- A semiselective MRS medium, (Hi-media) was modified by adding a freshly prepared reducing solution $(1 \mathrm{ml})$ per $100 \mathrm{ml}$ of media (14) . the medium was prepared anerobically same as above

\section{4- Removal of oxygen from the media and other solutions}

The way to remove oxygen from heat stable solution is to boil it vigorously for about one minute then add reducing agent After boiling the media and solutions leave to cool and flushing with purified $\mathrm{CO}_{2}$ gas which is prepared in our anaerobe apparatus. Adequate amount from the media in the flask are transferred to roll tubes( this tubes sealed with rubber stopper and closed with screw in cap) that it contain agar these procedure under $\mathrm{CO}_{2}$ gas. These tubes containing medium can be sterilized in autoclave at $105 \mathrm{C}^{\circ}$ for 45 minutes after sterilization tor rolling tubes containing sterile medium with agar are rolling on ice or cold water which allowed the agar medium to distribute as a thin layer over the internal surface of test tubes , and a continuous flushing of $\mathrm{CO}_{2}$ during this procedure.

\section{4-Culturing of ruminal fluid on prepared media.}

Twenty ruminal fluid samples were collected from sheep fed on grain base diet at fourth and fifth days by rumenocentesis method, the fluids were emptied into plastic container, flushed with purified $\mathrm{CO}_{2}$ and transported immediately to the laboratory . At laboratory the fluids were mixed well and a subsample of $5 \mathrm{ml}$ of rumen fluids were mixed with $45 \mathrm{ml}$ of anaerobic dilution solution ( ADS) in a plastic container provide with rubber stopper,flushed with $\mathrm{CO}_{2}$

The homogenized samples serially diluted 10 -fold in ADS to a final dilution of $10^{7}$. Three dilutions $, 10^{5}, 10^{6}$ and $10^{7}$,were used to inoculate M-BA medium in hungate roll tubes in triplicate for each dilution the tubes were incubated at $39 \mathrm{C}^{\circ}$ for 48 hours .after incubation single colonies were picked from the roll tubes by using Pasteur pipette and inoculated into basal medium ( BM) broth dispensing in hungate tubes were incubated at $39 \mathrm{C}^{\circ}$ for 6-10 hours, this procedure was repeated at least twice to increase purification.

4- Stains:- Gram $\square$ s stain, Hiss capsular stain (15).

5-Physiological and biochemical tests were performed to insure the diagnosis of Streptococcus bovis include:- 

AL-Qadisiya Journal of Vet.Med.Sci.

Growth at different temperatures $\left(10 \mathrm{C}^{\circ}\right.$, $45 \mathrm{C}^{\circ}, 50 \mathrm{C}^{\circ}$ ), Growth in $2 \%$ and $6.5 \%$ $\mathrm{NaCl}$,

Catalase test, Carbohydrates fermentation (16) . Growth on potassium tellurite $(0.04 \%)$ (17).All previous testes were showed on a broth of basal medium which prepared anaerobically. Determination of ammonia produced from arginine (18), Measuring of

\section{Results}

Culture characteristic

Twenty seven isolates of streptococcus bovis were identified from the 20 ruminal fluid samples of sheep. Cultural characteristic on the selective medium MBA showed two types of streptococci : type 1(23) comprised the majority of isolates which characterized by high acid producing S.bovis formed mucoid ,creamy ,orange centered colonies (picture 2 ) and were similar in all respects except for the arabinose fermentation .while the second lactic acid accor according to (19), Hemolysis is detected in anaerobic roll tubes contains modified blood brain heart infusion agar ( 13) .

\section{6- Lancefield grouping of streptococcus:-}

The streptococcal isolates were also tested serologically for Lancefield group identification, using a rapid latex test system. (Massas Virginia, USA)

type(four isolates) characterize by Low acid producing formed small white colonies ( picture 3).In basal broth the bacterium grew rapidly during 6 hours and change medium from clear colour into milky color ( picture 4). All isolates showed no hemolysis on modified blood brain heart infusion (picture 5). Morphologically the organism was identified as gram positive and the stain more concentrated in the capsule the cells were oval or spherical, pairs, short chains of 4 to 8 cells and singles.(Picture 6)

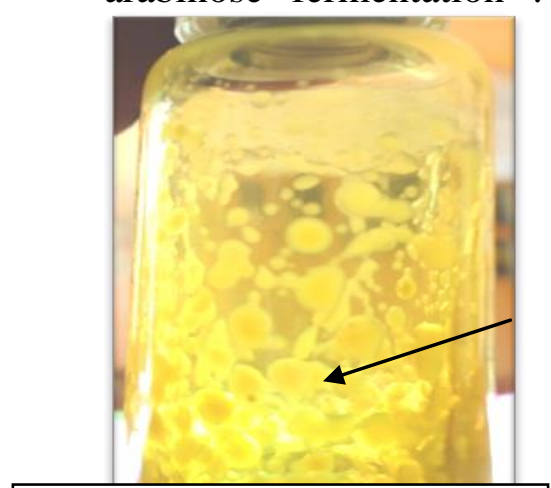

Picture (2)High acid producing S. bovis colonies

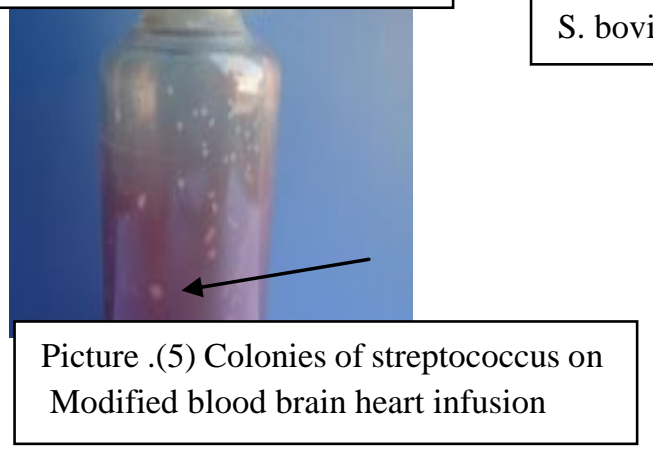

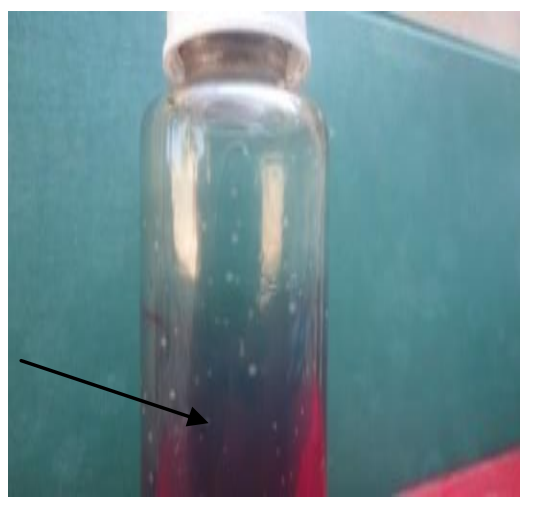

Picture (3)Low acid producing S. bovis colonies

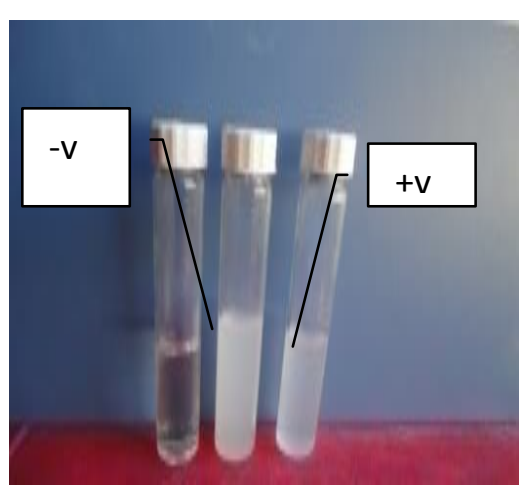

(4)Growing of streptococcus on basal broth
Picture (6). Gram stain of Streptococcus 

AL-Qadisiya Journal of Vet.Med.Sci.
Vol./12
No./1

Results of Physiological and biochemical

tests:-All isolated bacteria grew on basal broth post incubation at $45 \mathrm{C}^{\circ}$,but not grew on incubation at $10 \mathrm{C}^{\circ}$ and $50 \mathrm{C}^{\circ}$. Adding of $2 \% \mathrm{NaCl}$ to the broth of basal medium permit the growth while in $6.5 \% \mathrm{NaCl}$ didn't grow. And did not grew on $0.04 \%$ Potassium tellurite .All isolates produced lactic acid but ammonia production from arginine was negative.Each isolates fermented starch ,lactose ,fructose ,inulin ,glucose, raffinose and cellobiose and none of isolates ferminted of xylose ,mannitol, glycerol or sorbitol but some isolates gives positive result to arabinose . White pigmented isolates did not ferment inulin.The results of culturing and Physiological and biochemical tests showed that27 isolates has the characterictices of Streptococcus bovis in 3 types $\left(\mathrm{S}_{1}, \mathrm{~S}_{2} \& \mathrm{~S}_{3}\right)$ as showed in table (1)

Serological typing:-All isolates were belong to group D by using Lancefield grouping

Table -1. Showed the charactization of Streptococcus bovis

\begin{tabular}{|c|c|c|c|}
\hline Characterization & S1 (15 isolates) & $\mathrm{S} 2$ (8 isolates ) & S3 (4 isolates) \\
\hline Colony on M-BA & $\begin{array}{l}\text { Yellow, large,,creamy } \\
\text { orange in the center }\end{array}$ & $\begin{array}{l}\text { Yellow large ,creamy } \\
\text { orange in the center }\end{array}$ & $\begin{array}{l}\text { White small } \\
\text { pinpoint }\end{array}$ \\
\hline Catalase & Negative & Negative & Negative \\
\hline $\mathrm{NaCl} 2 \%$ & Growth & Growth & Growth \\
\hline $\mathrm{NaCl} 6.5 \%$ & no growth & No growth & No growth \\
\hline Growth at $45 \mathrm{C}^{\circ}$ & Growth & Growth & Growth \\
\hline Growth at $10 \mathrm{C}^{\circ}, 50 \mathrm{C}^{\circ}$ & no growth & No growth & No growth \\
\hline Potassium tellurite $0.04 \%$ & no growth & No growth & no growth \\
\hline $\begin{array}{l}\text { Production of } \mathrm{NH} 3 \text { from } \\
\text { arginine }\end{array}$ & -ve & -ve & -ve \\
\hline Production of lactic acid & High & High & Low \\
\hline Blood hemolysis & No hemolysis & No hemolysis & No hemolysis \\
\hline $\begin{array}{l}\text { starch ,lactose ,fructose, } \\
\text { glucose,raffinose\&cellobiose }\end{array}$ & + ve & $+\mathrm{ve}$ & + ve \\
\hline Inulin & $+v e$ & +ve & -ve \\
\hline $\begin{array}{l}\text { xylose ,mannitol, glycerol } \\
\text { and sorbitol }\end{array}$ & -ve & -ve & -ve \\
\hline Arabinose & -ve & $+\mathrm{ve}$ & -ve \\
\hline
\end{tabular}

\section{Discussion}

Streptococcus bovis is an indigenous resident in the gastrointestinal tracts of both humans and animals; it is one of the major causes of bacterial endocarditis and has been implicated in the incidence of human colon cancer (20). Certain feeding regimen in ruminants can lead to overgrowth of $S$. bovis in the rumen resulting in the over-production of lactate and capsular polysaccharide causing acute ruminal acidosis and bloat $(21,22,9)$.In our study the change of diet from roughage and alfa alfa to high grain base diet cause an increase in the number of $S$. bovis isolated from ruminal fluid of ten awassi sheep. this compatible with $(1,2)$ they found that $S$. bovis is a normal inhabitant of the rumen ecosystem are rarely greater than $10^{7} / \mathrm{ml}$, but its numbers can increase to $10^{10}$ when large quantities of starch or highly fermentable carbohydrates are added to the diet. Allison et al,(3) found that the rapidly switching from a forage to a grain diet effect 
the ruminal fermentation and can become unbalanced ,resulting in digestive disorders which may include lactate acidosis.Many researcher explained different methods for isolation of S.bovis under strict anaerobe culture by a roll-tube $(2,4,23)$. So this study need to design anaerobe apparatus for increase purity of commercial $\mathrm{CO}_{2}$ gas , which give $\mathrm{O}_{2}$ free $\mathrm{CO}_{2}$ used in all steps of preparing media and culturing of organism.Results of culturing showed three types of streptococcus on a selective media MBA medium, two types colonies showed large yellow colonies with orange center and that were predominant in sheep fed with grain base diet and the third type showed small white pinpoint colonies, this similar as mentioned previously by $(14,24)$.All isolated $S$. bovis produce lactic acid( two type produce high amount and the third type produce low amount) this compatible with study of (5) they found that the main L- lactate producers were those isolates closely related to $S$. bovis, $S$. ruminantium and Lactococcus garvieae. Xu and Ding (25) have reported the importance of physiology, biochemistry and pathophysiology of fermentative acidosis in ruminant which is related to many factors and not due to the level of lactic acid production only. Gozho et al ,26) found that the drop of $\mathrm{pH}$ lead to proliferate of lactic acid producing bacteria such as S.bovis and lactobacillus's spp, leading to accumulation of lactic acid, which is known as lactic acidosis.In conclusion, our experimental study showed that the change of diet from roughage and alfa alfa to concentrate lead to an increase in the number of $S$. bovis isolated from ruminal fluid of sheep used, by different methods of culturing with importance of design a modified anaerobe apparatus for increase purity of commercial $\mathrm{CO}_{2}$ gas.
1. Hungate RE, RW Dougherty, MP Bryant, and. RW Cello, 1952. Microbiological and physiological changes associated with acute indigestion in sheep. Cornell Vet.42:pp421.

2. Hungate RE, 1969. A roll tube method for cultivation of strict anaerobes, pp. 117-132. In Norris JR and DW Ribbons(ed.),Methods in microbiology,vol.3B. Academic Press Inc., New York.

3. Allison, MJ, IM Robinson, RW Dougherty, and JA Bucklin, 1975. Grain overload in cattle and sheep: changes in microbial populations in the cecum and rumen. Am. J. Vet. Res. 36: $\quad$ pp181-185.

4. Ghali MB, PT Scott, RAM Al Jassim, 2004. Characterization of Streptococcus bovis from the rumen of the dromedary camel and Rusa deer. Lett Appl Microbiol; 39: pp341-6.

\section{References}

5. Ghali MB, PT Scott, GA Alhadrami, RAM Al-Jassim, 2011. Identification and characterization of the predominant lactic acidproducing and lactic acid-utilizing bacteria in the foregut of the feral camel (Camelus dromedarius) in Australia. Animal Production Science 51(7) 597-604.

6. Radositis OM,CC Gay,KW Hinchliff,et al ,2007,Veterinary Medicine. $10^{\text {th }}$ ed New York Oxford Philadelphia 314-325

7. Garry F and C McConnel, 2009. Indigestion in ruminants in: Smith BP, eds.Large animal internal medicine $.3^{\text {rd }}$ ed. Mosby, 824-830.

8. Calsamiglia S, M Blanch,A Ferret,D Moya ,2012.Is subacute ruminal acidosis a $\mathrm{pH}$ related problem? Causes and tools for its control. Animal Feed Science and Technology, Volume 172, Issues 12, 28 February, pp 42-50. 
9. Kamra DN, 2005. Rumen microbial ecosystem, Microbiology Section, Centre of Advanced Studies in Animal Nutrition, Indian Veterinary Research Institute, Izatnagar 243 122, India Current Science, Vol. 89, No. 1:124-135.

10. Latham J.and E Sharpe, 1971.The isolation of anaerobic organisms from the bovine rumen.In Isolation of Anaerobes.Eds DA Shapton \& RG Board.London and New York:Academic Press.

11. Oragui JI and DD Mara,1984. A note on a modified membrane-bovis agar for the enumeration of Streptococcus bovis by membrane filtration. J. Appl. Bacteriol. 56:179-181.

12. Russell JB and HJ Strobel ,1989. Effects of ionophores on ruminal fermentation. Appl. Environ. Microbiol. 55:1.

13. Macy JM, JE Snellen and RE Hungate ,1972. Use of syringe methods for anaerobiosis. Amer. J. Clin. Nutr.25:pp1318-1323.

14. Al Jassim RAM. and JB, Rowe,1999. Better understanding of acidosis and its control. Recent Adv. Anim. Nutr. Aust. 12, pp91-97.

15. Coles EH, 1986. Veterinary Clinical Pathology, 4th Ed.W.B.Saunder Co.Philadehia, London.

16. Russell JB and PG Robinson, 1984. Composition and characteristics of strains of Streptococcus bovis. J. Dairy Sci. 67:1525-1531.

17. Jones D, MJ Sackin \& PHA Sneath, 1972. A numerical taxonomic study of streptococci of serological group D. J Gen Microbiol 72, pp439-450.

18. Chaney AL and EP Marbach, 1962. Modified reagents for determination of urea and ammonia. Clin. Chem. 8:pp130-132.
19. Oser BL, 1965. Hawk,s physiological chemistery, $14^{\text {th }}$ Ed. McGraw - Hill New York.

20. Herrera,P;Kwon,Y.M and Ricke,S.C (2009). Ecology and pathogenicity of gastrointestinal Streptococcus bovis. Anaerobe, 15-(1=2):pp44-54.

21. Dehkordi A.J, Mohammad, R.H.H Dehkordi, Z.K. 2011. ECG Changes in acute Experimental ruminal lactic acidosis in sheep. Veterinary Research Forum.Vol. 2,No3.Pp 203-208.

22. Lettat,A;Noziere,P;Silberberg,M;Morga ve,D.P;BergerBand,C;Martin(2011) .Experimental feed induction of ruminal lactic ,propionic,or butyric acidosis in sheep.journal of animal science ,88,pp3041-3046.

23. Guo. T.J, JQ Wang, DP Bu, KL Liu ,JP Wang , D Li, SY Luan,2010. Evaluation of the microbial population in ruminal fluid using real time PCR in steers treated with virginiamycin. Czech J.Animal .Sci,55,(7) ,pp 276-285.

24. Al Jassim, RAM, GLR Gordon, and JB Rowe, 2003. The effect of basal diet on lactate- producing bacteria and the susceptibility of sheep to lactic acidosis. Animal Science 77, pp 459-469

25. Xu, Y and Ding,Z(2011). physiological ,biochemical and histopathological effects of fermentative acidosis in ruminant production :a minimal review. Spanish journal of agricultural research,9,(2) pp 414422.

26. Gozho GN,JC Plazier and DO Krause, 2007. Ruminal lipopolysaccharide concentration and inflammation response during grain induced sub acute ruminal acidosis in dairy cows. J.Dairy Sci, 90,pp856-866. 


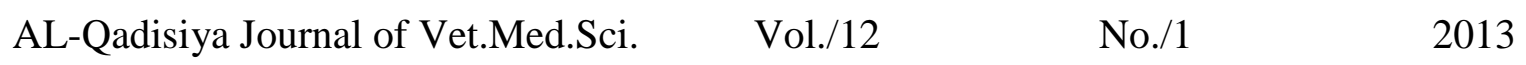

\title{
عزل وتوصيف بكتريا Streptococcus bovis من محتويات الكرش من الاغنام العواسي في العراق
}

\author{
اسعد جاسم عبد العمري عفاف عبدالرحمن يوسفر حمادي عبطان الهلالي
}

الخلاصة

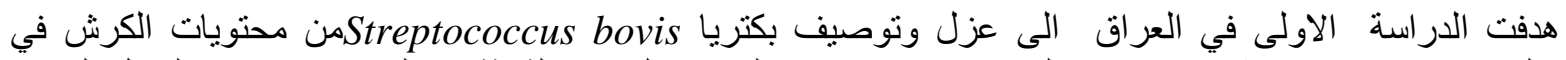

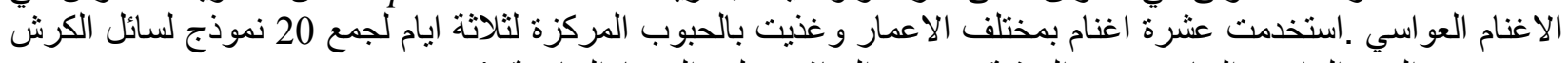

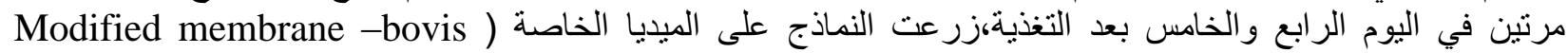

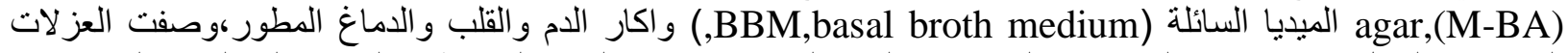

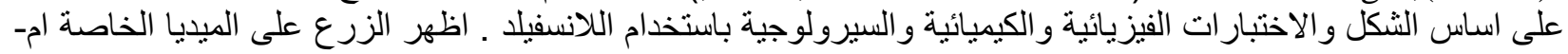

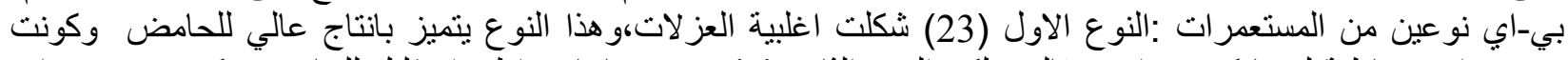

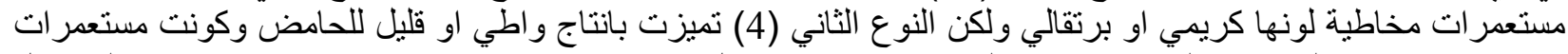

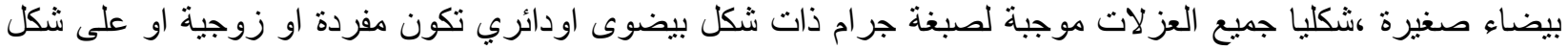

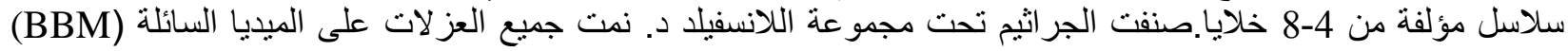

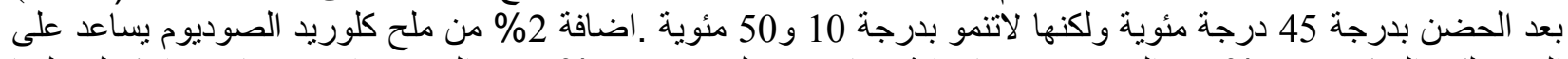

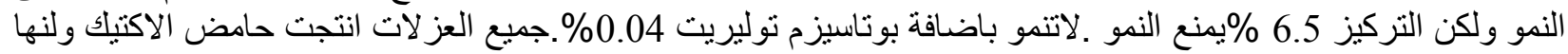

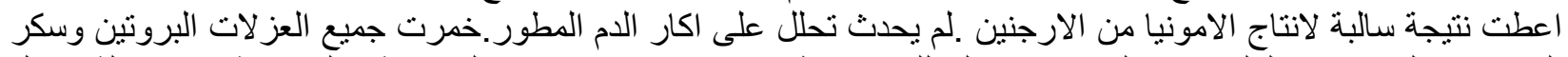

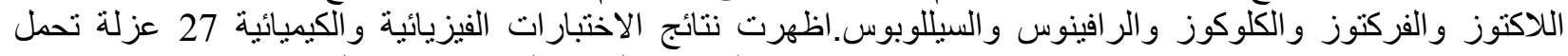

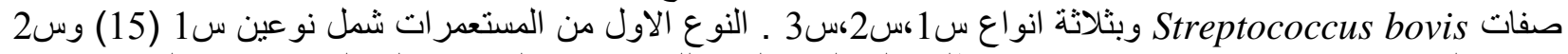
(8)تبعا للاختلاف في تخمير الار ابنوز .وس3 اطلق على النوع الثاني للمستعمر ات البيضاء والتي لم تخمر الاتيولين. 